\title{
The Renin-Angiotensin System in the Central Nervous System and Its Role in Blood Pressure Regulation
}

\author{
Pablo Nakagawa $^{1} \cdot$ Javier Gomez $^{1} \cdot$ Justin L. Grobe ${ }^{1} \cdot$ Curt D. Sigmund ${ }^{1}$ \\ Published online: 10 January 2020 \\ (C) Springer Science+Business Media, LLC, part of Springer Nature 2020
}

\begin{abstract}
Purpose of the Review The main goal of this article is to discuss how the development of state-of-the-art technology has made it possible to address fundamental questions related to how the renin-angiotensin system (RAS) operates within the brain from the neurophysiological and molecular perspective.

Recent Findings The existence of the brain RAS remains surprisingly controversial. New sensitive in situ hybridization techniques and novel transgenic animals expressing reporter genes have provided pivotal information of the expression of RAS genes within the brain. We discuss studies using genetically engineered animals combined with targeted viral microinjections to study molecular mechanisms implicated in the regulation of the brain RAS. We also discuss novel drugs targeting the brain RAS that have shown promising results in clinical studies and trials.

Summary Over the last 50 years, several new physiological roles of the brain RAS have been identified. In the coming years, efforts to incorporate cutting-edge technologies such as optogenetics, chemogenetics, and single-cell RNA sequencing will lead to dramatic advances in our full understanding of how the brain RAS operates at molecular and neurophysiological levels.
\end{abstract}

Keywords Renin $\cdot$ Prorenin receptor $\cdot$ Angiotensin receptor $\cdot$ Biased agonist $\cdot$ Blood pressure $\cdot$ Neurophysiology

\section{Introduction}

The physiological relevance of the renin angiotensin system (RAS) in blood pressure regulation and electrolyte homeostasis is well established and undisputable. The RAS is traditionally described as a hormone system, which promotes arterial blood pressure elevation primarily by inducing vasoconstriction, sodium retention, and aldosterone release. The sustained overactivation of the RAS could lead to hypertension, a disease affecting almost half of US American adults [1]. The activation of the endocrine RAS is initiated upon the release of renin from juxtaglomerular cell granules into the circulation. By catalyzing the cleavage of angiotensinogen to release angiotensin I peptide, renin acts as the rate limiting enzyme of the RAS, at least in humans. Thus, it is not surprising that

This article is part of the Topical Collection on Inflammation and Cardiovascular Diseases

Curt D. Sigmund

csigmund@mcw.edu

1 Department of Physiology, Cardiovascular Center, Medical College of Wisconsin, Milwaukee, WI 53226, USA there are a number of complex mechanisms regulating renin expression and secretion [2]. The subsequent conversion of angiotensin (ANG)-I to ANG-II is catalyzed by angiotensin converting enzyme (ACE) which is localized to endothelial cells and is abundant in the lungs. Most of the functions inducing blood pressure elevation are mediated through binding of ANG-II to angiotensin type 1 receptor $\left(\mathrm{AT}_{1} \mathrm{R}\right)$, whereas, binding of ANG-II to angiotensin type II receptors $\left(\mathrm{AT}_{2} \mathrm{R}\right)$ has been reported to generally oppose the actions of $A T_{1} R$. Other peptides of the RAS, such as ANG-(1-7) and alamandine, also act to counter regulate the action of ANGII at $\mathrm{AT}_{1} \mathrm{R}[3,4]$. Drugs targeting the RAS are effective as treatments for hypertension and other diseases including heart failure, chronic kidney disease, diabetic nephropathy, Marfan's syndrome, and some autoimmune diseases [5-10]. However, it is unclear why these drugs are effective even in patients exhibiting low or normal circulating renin activity $[11,12]$. The answer to this observation may lie in the existence of an independent autocrine/paracrine RAS acting locally within several tissues, including the brain.

The existence of the brain RAS, which was initially proposed by Bickerton and Buckley in 1961, has changed the traditional view of the RAS [13]. Since the discovery that 
central ANG-II induces a potent pressor response, several new functions of the brain RAS have been identified. Central administration of ANG-II elicits potent dipsogenic responses, induces sodium intake, triggers sympathetic outflow to the kidney and other organs, and recently, evidence has established that the brain RAS modulates metabolic function primarily through distinct nuclei within the hypothalamus [14-17]. Most of these effects can be attenuated by administration of RAS blockers or by genetically ablating $\mathrm{AT}_{1} \mathrm{R}$ in specific brain regions or cell types [18-20].

Resistant hypertension, in which high blood pressure remains above 140/90 $\mathrm{mmHg}$ despite use of 3 or more antihypertensive drugs (including a diuretic), accounts for approximately $10 \%$ of patients with essential hypertension [21]. Resistant hypertension and sympathetic overactivity have been linked to brain RAS overactivation [22]. Thus, novel drugs targeting the brain RAS might be useful to treat resistant hypertension and/or diseases associated with elevated sympathetic outflow such as heart failure [23]. This article aims to bring the reader up-to-date on the important new findings and the currently controversial topics in the field. Then, novel translatable strategies to attenuate the upregulation of brain RAS activity in human resistant hypertension will be also discussed.

\section{Role of Renin in the Generation of ANG-II Within the CNS}

Although more than 50 years of research supports the important role of the brain RAS in modulating several physiological functions, it is not completely clear how angiotensin peptides are generated within the central nervous system (CNS). There is extensive evidence indicating that angiotensinogen is highly expressed in astrocytes and in some specific populations of neurons, which suggests that the extracellular space of the CNS has abundant renin substrate [19, 24-28]. The distribution of the two main ANG-II receptors, $\mathrm{AT}_{1} \mathrm{R}$ and $\mathrm{AT}_{2} \mathrm{R}$, was mapped initially by autoradiography and subsequently confirmed by either in situ hybridization or utilizing transgenic mice expressing reporter genes under the control of either $\mathrm{AT}_{1} \mathrm{R}$ or $\mathrm{AT}_{2} \mathrm{R}$ promoters $[29,30,31 \bullet] . \mathrm{AT}_{1} \mathrm{R}$ is highly expressed in most of the circumventricular organs such as the subfornical organ, the organum vasculosum laminae terminalis (OVLT), and the area postrema. However, the elevated expression of $\mathrm{AT}_{1} \mathrm{R}$ in some regions behind the bloodbrain barrier such as the paraventricular nucleus of the hypothalamus (PVN), the nucleus tractus solitarius (NTS), the rostral and caudal ventrolateral medulla (RVLM and CVLM, respectively), the medial preoptic nucleus (MnPO), and some neurons within the arcuate nucleus (ARC) suggests a role for ANG-II as a neuromodulator. Expression of $\mathrm{AT}_{2} \mathrm{R}$ in the brain predominates over $\mathrm{AT}_{1} \mathrm{R}$ expression during fetal development
[32]. However, recent studies from De Kloet et al. utilizing bacterial artificial chromosome transgenic $\mathrm{AT}_{2} \mathrm{R}$-enhanced green fluorescent protein (eGFP) reporter mouse confirmed the presence of $\mathrm{AT}_{2} \mathrm{R}$ in adult brains particularly in neurons and/or fiber terminals in circumventricular organs, hypothalamic nuclei, and the hindbrain [30].

Although most of the components of the RAS have been identified in the brain, the lack of a reliable method to detect renin in small neuroanatomical structures had led some to question whether the central generation of ANG-II requires renin. Indeed, renin-independent ANG-II generating biochemical pathways involving tonin and cathepsin $\mathrm{D}$ have been proposed [33-36]. Others have performed experiments which they interpret as a refutation of the brain RAS [37]. The difficulties in measuring renin stem from several factors. First, considering that renin is the rate-limiting enzyme for the generation of ANG-I, and given the elevated bioavailability of angiotensinogen in the extracellular space of the brain, it is expected renin must be tightly controlled and secreted from specific cells within selected neuroanatomical nuclei. Supporting this, minimal elevation of ANG-II levels in discrete neuroanatomical regions is expected to elicit extremely profound effects. Indeed, evidence indicates that ablation or stimulation of angiotensinergic signaling within a few cells in the brain leads to extremely prominent cardiovascular and metabolic phenotypes [38-40]. Second, we and others have described the existence of an alternative renin isoform termed renin-b, which is the predominant transcribed renin isoform in the brain, but is absent in other tissues [41, 42]. Renin-b lacks the signal peptide and the first third of the pro-segment which implies that (1) renin-b protein is catalytically active and (2) is predicted to remain in an intracellular compartment [43]. This observation was particularly compelling as an intracrine RAS had been previously proposed $[44,45]$. Notably, evidence that ANG-II can be generated intracellularly in presynaptic neurons and subsequently released to the synaptic terminal upon presynaptic depolarization would provide a strong argument to define ANG-II as a neurotransmitter. To test the hypothesis that renin-b is involved in the generation of intracellular ANGII in the brain, we generated transgenic mice lacking the alternative renin-b, while renin-a was preserved [46]. Paradoxically, mice lacking renin-b exhibited a mild increase in blood pressure during the light cycle, which was attenuated by intracerebroventricular infusions of $\mathrm{AT}_{1} \mathrm{R}$ blockers or ACE inhibitors [47•]. These data indicate that intracellular renin-b might play a regulatory role on the brain RAS rather than generating intracellular ANG-II as initially proposed [46]. Even though our data do not support the existence of an intracellular ANG-II generating mechanism, they neither disprove it.

The brain is one of the most vascularized systems because it receives $8.6-20.4 \%$ of total cardiac output; thus, distinguishing renin levels generated within brain tissues (autocrine/paracrine) from the circulating renin (endocrine) is extremely challenging 
[48]. Despite evidence that renin activity and ANG-II have been identified in the cerebrospinal fluid (CSF) and brain tissues from nephrectomized animals, those who resist the existence of the brain RAS postulated that samples must be contaminated with traces of trapped blood [49-57]. Following this rationale, Van Thiel and colleagues attempted to provide evidence that the brain lacks the capacity to generate ANG-II by measuring renin activity (angiotensin-generating activity) in brain structures before and after organ buffer perfusion [37]. It is not surprising that there was a significant decrease in renin activity within several brain structures after buffer perfusion because (1) the brain has blood, and (2) neurons unlikely store renin within granules as do specialized renal juxtaglomerular cells. Indeed, the most direct and accurate conclusion from this study was that the brain indeed contains blood. It is surprising the authors decided to ignore their own data that renin activity remained at detectable levels in some buffer-perfused tissues including the brainstem. This is particularly interesting because in a double-transgenic mouse in which enhanced green fluorescence protein (GFP) is expressed under the control of the renin promoter and $\beta$-galactosidase is controlled by the angiotensinogen promoter, we identified unique reninexpressing cells in close proximity to angiotensinogenexpressing cells specifically within the RVLM, a brainstem nucleus $[58,59]$.

It is of utmost importance that one contrasts a classical endocrine system and views the brain RAS as a neuroendocrine, autacoid, or neurotransmitter system where single neurons or small collections of neurons mediate output from the CNS. Thus, cellular, neuroanatomical, and molecular specificities are the key aspects to be considered when neuroendocrine systems, such as the brain RAS, are studied. It remains unfortunate that equivocal interpretations from experiments lacking sensitivity and neuroanatomical selectivity, those which are not required when studying the classical RAS, re-emerge from time to time to question the existence of the brain RAS [60]. In the final section of this article, we will discuss how the development of state-of-the-art technology to study precise molecular signaling and neuronal circuits within the CNS are appropriate to elucidate the key mechanisms regulating generation and action of angiotensin peptides within different neuroanatomical regions.

\section{Activation of Renin by Prorenin Receptor}

The proteolytic activation of prorenin that normally occurs in secretory granules in renal JG cells is unlikely to occur in extrarenal tissues, including the brain [61]. Thus, it has been proposed that activation of renin in extrarenal tissues requires its binding to ATPase $\mathrm{H}(+)$-transporting lysosomal accessory protein 2, also known as the prorenin receptor (PRR), encoded by the ATP6ap2 gene. PRR has the unique capability to bind prorenin and induce its activation without prosegment removal [62]. PRR is highly expressed in neurons and some microglia cells and has been detected in several brain regions implicated in cardiovascular and autonomic control including the subfornical organ (SFO), paraventricular nucleus (PVN), nucleus of the solitary tract (NTS), and the rostral ventrolateral medulla (RVLM) [63•, 64]. Despite initial reports indicating that PRR might be involved in hypertension through local generation of ANG-II, other roles that are independent of RAS activation have been described (reviewed in [65]). For instance, the transmembrane domain of the PRR interacts with the vacuolar $\mathrm{H}(+)$-ATPase and plays an important role in lysosomal function and neuronal development [66]. In humans, a unique mutation (c.321C > T, p.D107D) in the PRR locus is associated with X-linked mental retardation and epilepsy [67]. Although many RAS-independent functions of PRR are well defined in kidney, the RAS-independent functions of PRR in the brain are not completely understood $[49,66,68-70]$.

In mice where neuronal PRR was ablated at embryonic day $\sim 18.5$ (neuron filament promoter-CRE crossed with PRRfloxed mice; Nefh-PRRKO), central generation of ANG-II in response to intracerebroventricular administration of recombinant prorenin was attenuated. To study the role of neuronal PRR in the pathogenesis of hypertension, Feng's lab utilized the model of low-renin hypertension induced by deoxycorticosterone acetate (DOCA) infusion and high dietary sodium. Intracerebroventricular infusion of ACE inhibitor prevents and reverses high blood pressure, demonstrating that production of ANG-II in the brain is required for DOCA-salt hypertension even though circulating RAS activity is suppressed [71]. Moreover, two separate studies have shown that central infusion of an $\mathrm{AT}_{1} \mathrm{R}$ blocker mimics the effects of central delivery of ACE inhibitors [72, 73]. Thus, it is well accepted that the blood pressure elevation in DOCA-salt hypertension is strongly driven by a neurogenic mechanism involving activation of the brain RAS [74].

$\mathrm{Li}$ et al. reported that the selective ablation of PRR in neurons attenuated the elevation of blood pressure in DOCA-salt hypertension when $0.9 \mathrm{M} \mathrm{NaCl}$ was the only fluid offered [75]. In contrast, experiments where DOCA-treated NefhPRRKO mice were exposed to two-bottle choice paradigm for the assessment of sodium preference revealed that the ablation of PRR in neurons is insufficient to decrease blood pressure but suppressed DOCA-induced saline intake [76]. These data suggest expression of PRR in specific brain regions controlling drinking behavior, such as the SFO is of physiological relevance. Recently, Souza and colleagues examined the role of PRR in the PVN, a key integratory nucleus involved in blood pressure control [77]. In this study, PVNtargeted ablation of PRR was induced in PRR-floxed mice by bilateral stereotactic microinjection of adeno-associated virus (AAV)-CRE-GFP. The reduction of PRR expression in the PVN by less than $50 \%$ was sufficient to attenuate DOCA- 
salt induced blood pressure elevations, cardiac and vasomotor sympathetic over-activity, and improved cardiac parasympathetic function [63•]. In addition, live-cell calcium recordings utilizing a novel calcium biosensor (GCaMP6) revealed PVNtargeted ablation of PRR attenuates calcium influx in response to ANG-II in DOCA-salt hypertension. Despite the growing evidence indicating the importance of PRR in the CNS to control cardiovascular function, there is no generalized consensus whether the underlying mechanisms require local ANG-II generation. It is likely that both ANG-II-dependent and ANG-II-independent mechanisms might occur simultaneously at different degrees depending on the neuroanatomical localization and cell types, as well as different physiological and pathological circumstances [78].

There is a growing interest in the soluble PRR fragment (sPRR) which arises from the proteolytic cleavage of PRR by furin or site- 1 protease to generate a $10-\mathrm{kD}$ transmembrane/ cytoplasmic fragment and a $28-\mathrm{kD}$ soluble PRR form [79, 80]. Growing evidence supports that elevation of circulating sPRR levels are associated with high blood pressure, chronic kidney disease, preeclampsia, and obstructive sleep apnea [81-84]. However, the biological function and the physiological relevance of sPRR were completely unknown until recently. Many functions of sPRR controlling renal function have been reported. For instance, sPRR exerts antidiuretic actions in part by inducing frizzled 8 -dependent stimulation of aquaporin 2 expression in the collecting duct [49]. Studies specifically aiming to elucidate the role of SPRR in the CNS have not been reported. Recently, Gatineau et al. demonstrated that the selective deletion of adipose tissue PRR elevates systolic blood pressure concomitant with increased circulating SPRR levels in high fat diet-fed mice [85॰]. In males, systemic infusion of recombinant mouse epitope tagged sPRR resulted in blood pressure elevation and this increase was attenuated by ganglionic blockade, but not administration of $\mathrm{AT}_{1} \mathrm{R}$ blockers, indicating that autonomic dysfunction, but not circulating RAS overactivation, is a key mechanism underlying sPRR-mediated blood pressure elevation in obese male mice. In contrast, infusion of sPRR in females failed to induce autonomic dysfunction but it induced elevated vasopressin levels and plasma renin indicating the existence of sex differences in sPRR-mediated responses [86]. Given that the source of vasopressin is exclusively from the PVN and supraoptic nucleus (SON), these observations support that SPRR is biologically active in the CNS and elevations of SPRR in the brain might be implicated in certain forms of neurogenic hypertension linked to obesity.

\section{Advances on the Protective Arm of the Brain RAS}

It has been proposed that many of the effects of ANG-(1-7) in the CNS oppose many of the $\mathrm{AT}_{1} \mathrm{R}$-mediated actions of ANG-
II in the brain [87]. ANG-(1-7) induces its effects mainly through Mas receptor activation, although it has been reported to also act through $\mathrm{AT}_{2} \mathrm{R}$ [88]. Other studies proposed that Mas receptors form heterodimers with $\mathrm{AT}_{2} \mathrm{R}$ in astrocytes [89]. Teixeira et al. recently reported that ANG-(1-7) binds to $\mathrm{AT}_{1} \mathrm{R}$ but fails to engage its canonical $\mathrm{G}$ protein signaling [90]. Instead, ANG-(1-7) triggers $\beta$-arrestin recruitment and intracellular signaling, suggesting it may have the properties of a biased agonist for $A_{1} R$. Several synthetic $A_{1} R$ biased agonists have been designed, but the existence of an endogenous functional biased ligand for $\mathrm{AT}_{1} \mathrm{R}$ has not been reported. ANG-(1-7) can be generated from the direct cleavage of ANG-II by angiotensin converting enzyme 2 (ACE2), but ACE2 can also catalyze the conversion of angiotensin I to Angiotensin-(1-9), which subsequently is converted to ANG-(1-7) by ACE or neutral endopeptidase [91]. Downregulation of ACE2 and suppression of central ANG-(1-7) levels are thought to be one of the underlying mechanisms causing low renin hypertension [20,92].

In recent years, significant progress has been achieved particularly on the molecular mechanisms controlling brain ACE2 activity. Lambert et al. described a process termed "ACE2 shedding" in which a disintegrin and metalloprotease 17 (ADAM17) catalyze the cleavage of membrane anchored ACE2 [93]. However, advances on the physiological and pathophysiological role of ADAM17-mediated ACE2 shedding in the brain have only been recently demonstrated. Xia and Sriramula et al. demonstrated that neuron-targeted overexpression of ACE2 is sufficient to ameliorate elevated blood pressure, autonomic dysfunction, and vasopressin release in response to DOCA-salt hypertension [94]. Moreover, braintargeted ablation of ADAM17 utilizing central infusions of siRNA suppressed DOCA-salt induced hypertension concomitant with blunted reduction of ACE2 activity in the hypothalamus and cerebrospinal fluid, indicating that ACE2 shedding by ADAM17 in the brain is a relevant mechanism contributing to neurogenic hypertension. New evidence indicates that activation of $\mathrm{AT}_{1} \mathrm{R}$ is required for ADAM17-mediated ACE2 shedding possibly via reactive oxygen species and phosphorylation of extracellular signal-regulated kinase in neurons [92]. It has been previously shown that a reduction of ACE2 expression in the RVLM is a contributing factor in the development of hypertension in spontaneously hypertensive rats [95]. Mukerjee et al. provided evidence of the importance of ACE2/ADAM17 pathway in pre-sympathetic neurons within the PVN [96•]. Interestingly, ACE2 is expressed in GABAergic inhibitory neurons projecting onto the hypothalamus. Thus, ACE2 is thought to maintain a normal GABAergic inhibitory tone to the presympathetic neurons in the PVN in normal physiological conditions, while disinhibition of this pathway might lead to hypertension. In contrast, ADAM17 is expressed in single-minded family basic helixloop helix transcription factor 1 (Sim1)-positive excitatory 
neurons within the PVN and promotes excitatory activity. Ablation of ADAM17 in the PVN blunts pressor responses to acute PVN-targeted microinjection of ANG-II. This accumulating evidence suggests the importance of the opposing roles of ACE2 and ADAM17 in modulating of sympathetic activity and central control of blood pressure. Finally, it has been recognized that ADAM17 has a role in processing the proinflammatory cytokine, tumor necrosis factor alpha $(\mathrm{TNF}-\alpha)$. Indeed, upregulation of the brain ADAM17 was associated with elevated TNF- $\alpha$ implicating that attenuation of TNF- $\alpha$-related mechanisms could be mediating part of the phenotype observed in mice lacking hypothalamic ADAM17. Numerous reports suggest elevation of TNF- $\alpha$ and activation of inflammatory cells (microglia) within certain brain regions triggers hypertensive responses [97-99]. Therefore, future studies are expected to clarify whether TNF- $\alpha$ plays a regulatory role in ACE2 activity and other RAS components.

\section{Novel Drugs to Modulate the Brain RAS and Potential New Clinical Applications}

A quarter of hypertensive patients exhibit low-renin hypertension [100]. It has been suggested that low-renin hypertension is in part driven by elevated angiotensinergic signaling in the brain $[71,101]$. Therefore, the development of novel drugs modulating the brain RAS might represent an effective solution to treat resistant hypertension coincident with elevated sympathetic activity and suppressed circulating renin activity. Two decades ago, Llorens-Cortes's laboratory demonstrated that the conversion of ANG-II into angiotensin III (ANG-III) in the brain is catalyzed by aminopeptidase A (APA), a zinc metalloprotease [102]. Importantly, ANG-III has been hypothesized to be the major biologically active peptide of the brain RAS. This is based on the observation that inhibition of the brain APA completely prevents elevated blood pressure in models of neurogenic hypertension with elevated brain RAS [103].

It took years to translate the observation that pharmacological inhibition of APA can be used as a therapeutic tool to treat resistant hypertension in humans. Recently, a new multicenter, open-label, phase II study was released evidencing the efficacy of a brain penetrating inhibitor of APA, firibastat (previously named RB150), in reducing blood pressure in overweight patients of multiple ethnic origins without angioedema [104•]. Moreover, an additional pilot double-blinded randomized placebo-controlled study in hypertensive patients demonstrated that blood pressure in firibastat-treated patients trended to be decreased compared to placebo controls without affecting systemic RAS activity [105]. Firibastat is the first oral medication that may target the brain RAS with promising clinical application. Current efforts in designing new brainpenetrating APA inhibitors led to a 10-fold more potent new prodrug, NI956/QGC006, which has been shown to exert powerful antihypertensive effects in rats treated with DOCA-salt [106].

In recent years, multiple pleiotropic roles of the brain RAS, namely neuroinflammation, autophagy, ER stress, and mitochondrial dysfunction, have emerged. These findings resulted in considerable advances in utilizing brain RAS blockade or RAS modulation as a therapeutic strategy to treat diseases beyond neurogenic hypertension. This is specifically relevant in stroke and cerebrovascular diseases, Alzheimer's disease, cognitive dysfunction, Parkinson disease, aging, and others [107-115]. Numerous other new molecules or administration routes to target the brain RAS are currently under investigation. For instance, new classes of $\mathrm{AT}_{1} \mathrm{R}$ biased agonists, which can selectively activate $\beta$-arrestin without activating the classical $\mathrm{G}$ protein-coupled signaling, might represent potential tools to modulate angiotensin signaling within the brain. For example, Carvalho-Galvão et al. demonstrated that intracerebroventricular infusion of TRV027, a $\beta$-arrestin-biased $\mathrm{AT}_{1} \mathrm{R}$-agonist effectively attenuated autonomic dysfunction and decreased arterial pressure in spontaneously hypertensive rats (SHR) [116]. Thus, the development of brain-penetrating $\mathrm{AT}_{1} \mathrm{R}$-biased agonists would be a promising strategy to treat resistant hypertension. Finally, Torika et al. demonstrated that intranasal administration of telmisartan is effective at reducing brain inflammation and ameliorating the progression of Alzheimer's disease in mice indicating that novel routes of administration can also be employed to inhibit the brain RAS without systemic off targets effects [117].

\section{Novel Technology to Study the Brain RAS}

The development of several cutting-edge technologies to study the CNS predicts that we might witness a profound advance in this field in the near future. Several laboratories are currently utilizing novel in situ hybridization techniques with significantly higher specificity and sensitivity. These are powerful tools to identify the anatomical and cellular localization of cells expressing components of the RAS within the CNS and to query the molecular and/or neural significance of these cells by multiplexing with different probes. We used RNAscope ${ }^{\circledR}$ technology to confirm the abundance of AGT and the presence of $\mathrm{AT}_{1} \mathrm{R}$ and PRR in discrete cells within the brain. Using this same technique, we and others have identified the distribution of RAS genes in specific NeuN+ neurons, GFAP+ astrocytes, and Iba-1+ microglia cells in the SFO, PVN, ARC, and the RVLM (unpublished). In addition, the development of an extensive array of transgenic mice carrying conditional alleles of RAS genes as well as mice expressing tamoxifen-inducible and/or cell-specific CRE recombinase expression facilitates further exploration of novel molecular and physiological functions of the RAS within specific cell types within the brain. Novel and previously generated animals expressing CRE recombinase 
under the control of specific promotors including $\mathrm{AT}_{1} \mathrm{R}$-CRE or Ren1-CRE mice, which can be crossed with mice expressing CRE-dependent TdTomato (or other reporter genes) as well as mice expressing a fluorescent reporter gene under the control of RAS genes such as $\mathrm{AT}_{2} \mathrm{R}$-eGFP or $\mathrm{AT}_{1 \mathrm{a}} \mathrm{R}$-EGFP (NZ44), allow fluorescent labelling of cells expressing RAS genes [30, $31 \cdot, 118,119]$.

Significant progress has been made in developing techniques to identify the distinct roles of specific neurons in the brain. These techniques include optogenetics and Designer Receptors Exclusively Activated by Designer Drugs (DREADD), a chemogenetic technique, in which neuronal activity can be stimulated or suppressed in specific brain nuclei utilizing light or designer drugs, respectively. Using these techniques, several laboratories recently showed the distinct roles of specific cells within selected nuclei controlling cardiovascular, metabolic, and autonomic function. For instance, De Kloet el al. recently reported that optogenetic stimulation of $\mathrm{AT}_{1} \mathrm{R}$ expressing neurons in the $\mathrm{PVN}$ promotes blood pressure elevation and activation of the hypothalamic-pituitary-adrenal axis [31•]. Similarly, Nation et al. utilized DREADDs to study the role of SFO neurons in thirst and salt appetite [120 $]$. Stimulation of neuronal firing and activation of $\mathrm{Gq}$ signaling in mice receiving SFO-targeted microinjection of a virus (AAV2-CaMKII-HAhM3D(Gq)-IRES-mCitrine) to induce selective neuronal expression of $\mathrm{G} \alpha \mathrm{q}$ via a designer receptor (hM3D) that is exclusively activated by clozapine $\mathrm{N}$-oxide, resulted in strong dipsogenic responses and preference to $0.3 \mathrm{M}$ saline. The combination of these novel techniques with the array of transgenic mice described above are powerful tools to inquire the responses to stimulating or inactivating different neuronal circuits in the CNS.

Finally, emerging "omics" techniques are becoming more accessible and reliable to study the transcriptome profile in different neuronal populations. There is particular interest in single-cell and single-nuclear RNA sequencing technology to identify different clusters expressing RAS genes to evaluate the molecular signature of cells. Although studies utilizing these techniques to specifically evaluate the brain RAS are not yet available, Sapouckey recently reported an in silico re-analysis of hypothalamic single-cell RNA sequencing datasets revealing that $\mathrm{AT}_{1} \mathrm{R}$ is expressed in a specific cluster of neurons expressing both Agouti-related peptide (AgRP) and leptin receptors $[121 \bullet]$. This seminal discovery may illuminate the underlying mechanisms by which the brain RAS controls resting metabolic rate and sympathetic activity in obesity-related hypertension.

\section{Conclusion}

Although the RAS in the brain has been studied for decades, interesting and seminal discoveries continue to be made to this day. These include assessing the functional significance of newly identified components of the RAS (such as prorenin receptor), the action of unconventional RAS peptides (such as ANG III), enzymes which modify RAS components (such as ADAM17), and new therapeutic tools to combat neurogenic hypertension. New technologies are making it easier to answer old questions - what is the localization of angiotensin receptors - and investigate new ones - what are function of specific subsets of $\mathrm{AT}_{1} \mathrm{R}$-containng neurons? New genomic technologies such as single cell sequencing will provide novel platforms to understand the diversity of neuronal types which respond to RAS activation or mediate downstream RAS signaling.

\section{Compliance with Ethical Standards}

Conflict of Interest The authors declare no conflicts of interest relevant to this manuscript.

Human and Animal Rights and Informed Consent This article does not contain any studies with human or animal subjects performed by any of the authors.

\section{References}

Papers of particular interest, published recently, have been highlighted as:

- Of importance

•• Of major importance

1. Mozaffarian D, Benjamin EJ, Go AS, Arnett DK, Blaha MJ, Cushman M, et al. Heart disease and stroke statistics-2015 update: a report from the American Heart Association. Circulation. 2015;131(4):e29-322. https://doi.org/10.1161/cir. 0000000000000152.

2. Sparks MA, Crowley SD, Gurley SB, Mirotsou M, Coffman TM. Classical renin-angiotensin system in kidney physiology. Compr Physiol. 2014;4(3):1201-28. https://doi.org/10.1002/cphy. c130040.

3. Sampaio WO, Henrique de Castro C, Santos RA, Schiffrin EL, Touyz RM. Angiotensin-(1-7) counterregulates angiotensin II signaling in human endothelial cells. Hypertension. 2007;50(6): 1093-8. https://doi.org/10.1161/hypertensionaha.106.084848.

4. Lautner RQ, Villela DC, Fraga-Silva RA, Silva N, Verano-Braga $\mathrm{T}$, Costa-Fraga F, et al. Discovery and characterization of alamandine: a novel component of the renin-angiotensin system. Circ Res. 2013;112(8):1104-11. https://doi.org/10.1161/ circresaha.113.301077.

5. Leon SJ, Tangri N. The use of renin-angiotensin system inhibitors in patients with chronic kidney disease. Can J Cardiol. 2019;35(9): 1220-7. https://doi.org/10.1016/j.cjca.2019.06.029.

6. Rossignol P, Hernandez AF, Solomon SD, Zannad F. Heart failure drug treatment. Lancet. 2019;393(10175):1034-44. https://doi. org/10.1016/s0140-6736(18)31808-7.

7. Lewis EJ, Lewis JB. Treatment of diabetic nephropathy with angiotensin II receptor antagonist. Clin Exp Nephrol. 2003;7(1):1-8. https://doi.org/10.1007/s101570300000. 
8. Hofmann Bowman MA, Eagle KA, Milewicz DM. Update on clinical trials of losartan with and without beta-blockers to block aneurysm growth in patients with Marfan syndrome: a review. JAMA Cardiol. 2019;4(7):702-7. https://doi.org/10.1001/ jamacardio.2019.1176.

9. Kitamura N, Matsukawa Y, Takei M, Sawada S. Antiproteinuric effect of angiotensin-converting enzyme inhibitors and an angiotensin II receptor blocker in patients with lupus nephritis. J Int Med Res. 2009;37(3):892-8. https://doi.org/10.1177/ 147323000903700335

10. Chang Y, Wei W. Angiotensin II in inflammation, immunity and rheumatoid arthritis. Clin Exp Immunol. 2015;179(2):137-45. https://doi.org/10.1111/cei.12467.

11. Wilkins LH, Dustan HP, Walker JF, Oparil S. Enalapril in lowrenin essential hypertension. Clin Pharmacol Ther. 1983;34(3): 297-302. https://doi.org/10.1038/clpt.1983.171.

12. Holland OB, von Kuhnert L, Campbell WB, Anderson RJ. Synergistic effect of captopril with hydrochlorothiazide for the treatment of low-renin hypertensive black patients. Hypertension. 1983;5(2):235-9. https://doi.org/10.1161/01.hyp. 5.2.235.

13. Bickerton RK, Buckley JP. Evidence for a central mechanism in angiotensin induced hypertension. Proc Soc Exp Biol Med. 1961;106(4):834-6. https://doi.org/10.3181/00379727-10626492.

14. Grobe JL, Grobe CL, Beltz TG, Westphal SG, Morgan DA, Xu D, et al. The brain renin-angiotensin system controls divergent efferent mechanisms to regulate fluid and energy balance. Cell Metab. 2010;12(5):431-42. https://doi.org/10.1016/j.cmet.2010.09.011.

15. Avrith DB, Fitzsimons JT. Increased sodium appetite in the rat induced by intracranial administration of components of the renin-angiotensin system. J Physiol. 1980;301:349-64. https:// doi.org/10.1113/jphysiol.1980.sp013210.

16. SEVERS WB, DANIELS AE, SMOOKLER HH, KINNARD WJ, JP BUCKLEY. Interrelationship between angiotensin II and the sympathetic nervous system. J Pharmacol Exp Ther. 1966;153(3):530-7.

17. Unger T, Becker H, Petty M, Demmert G, Schneider B, Ganten D, et al. Differential effects of central angiotensin II and substance P on sympathetic nerve activity in conscious rats. Implications for cardiovascular adaptation to behavioral responses. Circ Res. 1985;56(4):563-75. https://doi.org/10.1161/01.res.56.4.563.

18. Hilzendeger AM, Cassell MD, Davis DR, Stauss HM, Mark AL, Grobe JL, et al. Angiotensin type 1a receptors in the subfornical organ are required for deoxycorticosterone acetate-salt hypertension. Hypertension. 2013;61(3):716-22. https://doi.org/10.1161/ hypertensionaha.111.00356.

19. Sandgren JA, Linggonegoro DW, Zhang SY, Sapouckey SA, Claflin KE, Pearson NA, et al. Angiotensin AT1A receptors expressed in vasopressin-producing cells of the supraoptic nucleus contribute to osmotic control of vasopressin. Am J Physiol Regul Integr Comp Physiol. 2018;314(6):R770-r80. https://doi.org/10. 1152/ajpregu.00435.2017.

20. Xu J, Sriramula S, Xia H, Moreno-Walton L, Culicchia F, Domenig O, et al. Clinical relevance and role of neuronal AT1 receptors in ADAM17-mediated ACE2 shedding in neurogenic hypertension. Circ Res. 2017;121(1):43-55. https://doi.org/10. 1161/circresaha.116.310509.

21. Persell SD. Prevalence of resistant hypertension in the United States, 2003-2008. Hypertension. 2011;57(6):1076-80. https:// doi.org/10.1161/hypertensionaha.111.170308.

22. Oliva RV, Bakris GL. Sympathetic activation in resistant hypertension: theory and therapy. Semin Nephrol. 2014;34(5):550-9. https://doi.org/10.1016/j.semnephrol.2014.08.009.

23. Lefkowitz RJ, Rockman HA, Koch WJ. Catecholamines, cardiac beta-adrenergic receptors, and heart failure. Circulation.
2000;101(14):1634-7. https://doi.org/10.1161/01.cir.101.14. 1634.

24. Yang G, Gray TS, Sigmund CD, Cassell MD. The angiotensinogen gene is expressed in both astrocytes and neurons in murine central nervous system. Brain Res. 1999;817(1-2): 123-31. https://doi.org/10.1016/s0006-8993(98)01236-0.

25. Milsted A, Barna BP, Ransohoff RM, Brosnihan KB, Ferrario CM. Astrocyte cultures derived from human brain tissue express angiotensinogen mRNA. Proc Natl Acad Sci U S A. 1990;87(15): 5720-3. https://doi.org/10.1073/pnas.87.15.5720.

26. Stornetta RL, Hawelu-Johnson CL, Guyenet PG, Lynch KR. Astrocytes synthesize angiotensinogen in brain. Science. 1988;242(4884):1444-6. https://doi.org/10.1126/science. 3201232.

27. Intebi AD, Flaxman MS, Ganong WF, Deschepper CF. Angiotensinogen production by rat astroglial cells in vitro and in vivo. Neuroscience. 1990;34(3):545-54. https://doi.org/10. 1016/0306-4522(90)90163-x.

28. Agassandian K, Grobe JL, Liu X, Agassandian M, Thompson AP, Sigmund CD, et al. Evidence for intraventricular secretion of angiotensinogen and angiotensin by the subfornical organ using transgenic mice. Am J Physiol Regul Integr Comp Physiol. 2017;312(6):R973-r81. https://doi.org/10.1152/ajpregu.00511.2016.

29. Song K, Allen AM, Paxinos G, Mendelsohn FA. Mapping of angiotensin II receptor subtype heterogeneity in rat brain. J Comp Neurol. 1992;316(4):467-84. https://doi.org/10.1002/cne. 903160407.

30. de Kloet AD, Wang L, Ludin JA, Smith JA, Pioquinto DJ, Hiller $\mathrm{H}$, et al. Reporter mouse strain provides a novel look at angiotensin type-2 receptor distribution in the central nervous system. Brain Struct Funct. 2016;221(2):891-912. https://doi.org/10. 1007/s00429-014-0943-1.

31. de Kloet AD, Wang L, Pitra S, Hiller H, Smith JA, Tan Y, et al. A unique "angiotensin-sensitive" neuronal population coordinates neuroendocrine, cardiovascular, and behavioral responses to stress. J Neurosci. 2017;37(13):3478-90. https://doi.org/10. 1523/jneurosci.3674-16.2017 Utilizing optogenetics, the authors identified the role of AT1R expressing neurons within the paraventricular nucleus.

32. Grady EF, Sechi LA, Griffin CA, Schambelan M, Kalinyak JE. Expression of AT2 receptors in the developing rat fetus. J Clin Invest. 1991;88(3):921-33. https://doi.org/10.1172/jci115395.

33. Araujo RC, Lima MP, Lomez ES, Bader M, Pesquero JB, Sumitani M, et al. Tonin expression in the rat brain and toninmediated central production of angiotensin II. Physiol Behav. 2002;76(2):327-33. https://doi.org/10.1016/s0031-9384(02) 00720-5.

34. Genest J, Cantin M, Garcia R, Thibault G, Gutkowska J, Schiffrin E, et al. Extrarenal angiotensin-forming enzymes. Clin Exp Hypertens A. 1983;5(7-8):1065-80. https://doi.org/10.3109/ 10641968309048842.

35. Tonnaer JA, Wiegant VM, De Jong W. Angiotensin generation in the brain and drinking: indications for the involvement of endopeptidase activity distinct from cathepsin D. Brain Res. 1981;223(2):343-53. https://doi.org/10.1016/0006-8993(81) 91147-1.

36. Isa K, Garcia-Espinosa MA, Arnold AC, Pirro NT, Tommasi EN, Ganten D, et al. Chronic immunoneutralization of brain angiotensin(1-12) lowers blood pressure in transgenic (mRen2)27 hypertensive rats. Am J Physiol Regul Integr Comp Physiol. 2009;297(1):R1115. https://doi.org/10.1152/ajpregu.90588.2008.

37. van Thiel BS, Goes Martini A, Te Riet L, Severs D, Uijl E, Garrelds IM, et al. Brain renin-angiotensin system: does it exist? Hypertension. 2017;69(6):1136-44. https://doi.org/10.1161/ hypertensionaha.116.08922. 
38. Sakai K, Agassandian K, Morimoto S, Sinnayah P, Cassell MD, Davisson RL, et al. Local production of angiotensin II in the subfornical organ causes elevated drinking. J Clin Invest. 2007;117(4):1088-95. https://doi.org/10.1172/jci31242.

39. Claflin KE, Sandgren JA, Lambertz AM, Weidemann BJ, Littlejohn NK, Burnett CM, et al. Angiotensin AT1A receptors on leptin receptor-expressing cells control resting metabolism. J Clin Invest. 2017;127(4):1414-24. https://doi.org/10.1172/ jci88641.

40. Arnold AC, Sakima A, Kasper SO, Vinsant S, Garcia-Espinosa MA, Diz DI. The brain renin-angiotensin system and cardiovascular responses to stress: insights from transgenic rats with low brain angiotensinogen. J Appl Physiol (1985). 2012;113(12): 1929-36. https://doi.org/10.1152/japplphysiol.00569.2012.

41. Lee-Kirsch MA, Gaudet F, Cardoso MC, Lindpaintner K. Distinct renin isoforms generated by tissue-specific transcription initiation and alternative splicing. Circ Res. 1999;84(2):240-6. https://doi. org/10.1161/01.res.84.2.240.

42. Sinn PL, Sigmund CD. Identification of three human renin mRNA isoforms from alternative tissue-specific transcriptional initiation. Physiol Genomics. 2000;3(1):25-31. https://doi.org/10.1152/ physiolgenomics.2000.3.1.25.

43. Peters J, Wanka H, Peters B, Hoffmann S. A renin transcript lacking exon 1 encodes for a non-secretory intracellular renin that increases aldosterone production in transgenic rats. J Cell Mol Med. 2008;12(4):1229-37. https://doi.org/10.1111/j.1582-4934. 2008.00132.x.

44. Re RN. Role of intracellular angiotensin II. Am J Physiol Heart Circ Physiol. 2018;314(4):H766-h71. https://doi.org/10.1152/ ajpheart.00632.2017.

45. Singh VP, Le B, Bhat VB, Baker KM, Kumar R. High-glucoseinduced regulation of intracellular ANG II synthesis and nuclear redistribution in cardiac myocytes. Am J Physiol Heart Circ Physiol. 2007;293(2):H939-48. https://doi.org/10.1152/ajpheart. 00391.2007.

46. Grobe JL, Xu D, Sigmund CD. An intracellular renin-angiotensin system in neurons: fact, hypothesis, or fantasy. Physiology (Bethesda). 2008;23:187-93. https://doi.org/10.1152/physiol. 00002.2008.

47. Shinohara K, Liu X, Morgan DA, Davis DR, Sequeira-Lopez ML, Cassell MD, et al. Selective deletion of the brain-specific isoform of renin causes neurogenic hypertension. Hypertension. 2016;68(6):1385-92. https://doi.org/10.1161/hypertensionaha. 116.08242 This study describes how a selective ablation of the alternative intracellular renin isoform leads to paradoxical elevation of angiotensinergic signaling in the brain leading to elevated blood pressure.

48. Williams LR, Leggett RW. Reference values for resting blood flow to organs of man. Clin Phys Physiol Meas. 1989;10(3): 187-217. https://doi.org/10.1088/0143-0815/10/3/001.

49. Lu X, Wang F, Xu C, Soodvilai S, Peng K, Su J, et al. Soluble (pro)renin receptor via beta-catenin enhances urine concentration capability as a target of liver X receptor. Proc Natl Acad Sci U S A. 2016;113(13):E1898-906. https://doi.org/10.1073/pnas. 1602397113.

50. Healy DP, Printz MP. Distribution of immunoreactive angiotensin II, angiotensin I, angiotensinogen and renin in the central nervous system of intact and nephrectomized rats. Hypertension. 1984;6(2 Pt 2):I130-6. https://doi.org/10.1161/01.hyp.6.2_pt_2.i130.

51. Hutchinson JS, Csicsmann J. The distribution of immunoreactive angiotensins I and II extracted from rat brain. Acta Med Acad Sci Hung. 1978;35(3-4):277-85.

52. Phillips MI, Stenstrom B. Angiotensin II in rat brain comigrates with authentic angiotensin II in high pressure liquid chromatography. Circ Res. 1985;56(2):212-9. https://doi.org/10.1161/01.res. 56.2.212.
53. Hermann K, McDonald W, Unger T, Lang RE, Ganten D. Angiotensin biosynthesis and concentrations in brain of normotensive and hypertensive rats. J Physiol (Paris). 1984;79(6):47180 .

54. Inagami T, Yokosawa H, Hirose S. Definitive evidence for renin in rat brain by affinity chromatographic separation from protease. Clin Sci Mol Med Suppl. 1978;4:121s-3s. https://doi.org/10. $1042 / \mathrm{cs} 055121 \mathrm{~s}$.

55. Dzau VJ, Brenner A, Emmett N, Haber E. Identification of renin and renin-like enzymes in rat brain by a renin-specific antibody. Clin Sci (London). 1980;59 Suppl 6:45s-7s. https://doi.org/10. $1042 / \mathrm{cs} 059045 \mathrm{~s}$.

56. Ganten D, Minnich JL, Granger P, Hayduk K, Brecht HM, Barbeau A, et al. Angiotensin-forming enzyme in brain tissue. Science. 1971;173(3991):64-5. https://doi.org/10.1126/science. 173.3991.64.

57. Basso N, Ruiz P, Taquini AC. Angiotensin-forming enzyme active at the physiological $\mathrm{Ph}$ in the brain of normal and nephrectomized rats. Clin Exp Hypertens A. 1982;4(6):963-75. https://doi.org/10.3109/10641968209060765.

58. Lavoie JL, Cassell MD, Gross KW, Sigmund CD. Adjacent expression of renin and angiotensinogen in the rostral ventrolateral medulla using a dual-reporter transgenic model. Hypertension. 2004;43(5):1116-9. https://doi.org/10.1161/01.Hyp.0000125143. 73301.94.

59. Lavoie JL, Cassell MD, Gross KW, Sigmund CD. Localization of renin expressing cells in the brain, by use of a REN-eGFP transgenic model. Physiol Genomics. 2004;16(2):240-6. https://doi. org/10.1152/physiolgenomics.00131.2003.

60. Ren L, Lu X, Danser AHJ. Revisiting the brain renin-angiotensin system-focus on novel therapies. Curr Hypertens Rep. 2019;21(4): 28. https://doi.org/10.1007/s11906-019-0937-8.

61. Hirose S, Naruse M, Ohtsuki K, Inagami T. Totally inactive renin zymogen and different forms of active renin in hog brain tissues. $\mathrm{J}$ Biol Chem. 1981;256(11):5572-6.

62. Nguyen G, Delarue F, Burckle C, Bouzhir L, Giller T, Sraer JD. Pivotal role of the renin/prorenin receptor in angiotensin II production and cellular responses to renin. J Clin Invest. 2002;109(11):1417-27. https://doi.org/10.1172/jci14276.

63. LAC S, Worker CJ, Li W, Trebak F, Watkins T, AJB G, et al. (Pro)renin receptor knockdown in the paraventricular nucleus of the hypothalamus attenuates hypertension development and AT1 receptor-mediated calcium events. Am J Physiol Heart Circ Physiol. 2019;316(6):H1389-H405. https://doi.org/10.1152/ ajpheart.00780.2018 Utilizing a novel calcium biosensor, the authors demonstrate that ablation of prorenin receptor in the paraventricular nucleus attenuates angiotensin IIinduced calcium signaling in hypertension.

64. Xu Q, Jensen DD, Peng H, Feng Y. The critical role of the central nervous system (pro)renin receptor in regulating systemic blood pressure. Pharmacol Ther. 2016;164:126-34. https://doi.org/10. 1016/j.pharmthera.2016.04.006.

65. Bracke A, von Bohlen und Halbach O. Roles and functions of Atp6ap2 in the brain. Neural Regen Res. 2018;13(12):2038-43. https://doi.org/10.4103/1673-5374.241428.

66. Trepiccione F, Gerber SD, Grahammer F, López-Cayuqueo KI, Baudrie V, Păunescu TG, et al. Renal Atp6ap2/(pro)renin receptor is required for normal vacuolar H+-ATPase function but not for the renin-angiotensin system. J Am Soc Nephrol. 2016;27(11): 3320-30. https://doi.org/10.1681/asn.2015080915.

67. Ramser J, Abidi FE, Burckle CA, Lenski C, Toriello H, Wen G, et al. A unique exonic splice enhancer mutation in a family with $\mathrm{X}$-linked mental retardation and epilepsy points to a novel role of the renin receptor. Hum Mol Genet. 2005;14(8):1019-27. https:// doi.org/10.1093/hmg/ddi094. 
68. Ichihara A. (pro)renin receptor and autophagy in podocytes. Autophagy. 2012;8(2):271-2. https://doi.org/10.4161/auto.8.2. 18846.

69. Li C, Siragy HM. (Pro)renin receptor regulates autophagy and apoptosis in podocytes exposed to high glucose. Am J Physiol Endocrinol Metab. 2015;309(3):E302-10. https://doi.org/10. 1152/ajpendo.00603.2014.

70. Ramkumar N, Stuart D, Calquin M, Quadri S, Wang S, Van Hoek AN, et al. Nephron-specific deletion of the prorenin receptor causes a urine concentration defect. Am J Physiol Renal Physiol. 2015;309(1):F48-56. https://doi.org/10.1152/ajprenal.00126. 2015.

71. Itaya Y, Suzuki H, Matsukawa S, Kondo K, Saruta T. Central renin-angiotensin system and the pathogenesis of DOCA-salt hypertension in rats. Am J Phys. 1986;251(2 Pt 2):H261-8. https:// doi.org/10.1152/ajpheart.1986.251.2.H261.

72. Kubo T, Yamaguchi H, Tsujimura M, Hagiwara Y, Fukumori R. An angiotensin system in the anterior hypothalamic area anterior is involved in the maintenance of hypertension in spontaneously hypertensive rats. Brain Res Bull. 2000;52(4):291-6. https://doi. org/10.1016/s0361-9230(00)00266-5.

73. Park CG, Leenen FH. Effects of centrally administered losartan on deoxycorticosterone-salt hypertension rats. J Korean Med Sci. 2001;16(5):553-7. https://doi.org/10.3346/jkms.2001.16.5.553.

74. Basting T, Lazartigues E. DOCA-salt hypertension: an update. Curr Hypertens Rep. 2017;19(4):32-8. https://doi.org/10.1007/ s11906-017-0731-4.

75. Li W, Peng H, Mehaffey EP, Kimball CD, Grobe JL, van Gool JM, et al. Neuron-specific (pro)renin receptor knockout prevents the development of salt-sensitive hypertension. Hypertension. 2014;63(2):316-23. https://doi.org/10.1161/hypertensionaha.113. 02041 .

76. Trebak F, Li W, Feng Y. Neuronal (pro)renin receptor regulates deoxycorticosterone-induced sodium intake. Physiol Genomics. 2018;50(10):904-12. https://doi.org/10.1152/physiolgenomics. 00065.2018.

77. Basting T, Xu J, Mukerjee S, Epling J, Fuchs R, Sriramula S, et al. Glutamatergic neurons of the paraventricular nucleus are critical contributors to the development of neurogenic hypertension. J Physiol. 2018;596(24):6235-48. https://doi.org/10.1113/ jp276229.

78. Shi P, Grobe JL, Desland FA, Zhou G, Shen XZ, Shan Z, et al. Direct pro-inflammatory effects of prorenin on microglia. PLoS One. 2014;9(10):e92937. https://doi.org/10.1371/journal.pone. 0092937.

79. Cousin C, Bracquart D, Contrepas A, Corvol P, Muller L, Nguyen G. Soluble form of the (pro)renin receptor generated by intracellular cleavage by furin is secreted in plasma. Hypertension. 2009;53(6):1077-82. https://doi.org/10.1161/hypertensionaha. 108.127258 .

80. Nakagawa T, Suzuki-Nakagawa C, Watanabe A, Asami E, Matsumoto M, Nakano M, et al. Site-1 protease is required for the generation of soluble (pro)renin receptor. J Biochem. 2017;161(4):369-79. https://doi.org/10.1093/jb/mvw080.

81. Nishijima T, Tajima K, Takahashi K, Sakurai S. Elevated plasma levels of soluble (pro)renin receptor in patients with obstructive sleep apnea syndrome: association with polysomnographic parameters. Peptides. 2014;56:14-21. https://doi.org/10.1016/j. peptides.2014.03.008.

82. Hamada K, Taniguchi Y, Shimamura Y, Inoue K, Ogata K, Ishihara M, et al. Serum level of soluble (pro)renin receptor is modulated in chronic kidney disease. Clin Exp Nephrol. 2013;17(6):848-56. https://doi.org/10.1007/s10157-013-0803-y.

83. Watanabe N, Bokuda K, Fujiwara T, Suzuki T, Mito A, Morimoto $\mathrm{S}$, et al. Soluble (pro)renin receptor and blood pressure during pregnancy: a prospective cohort study. Hypertension.
2012;60(5):1250-6. https://doi.org/10.1161/hypertensionaha.112. 197418.

84. Morimoto S, Ando T, Niiyama M, Seki Y, Yoshida N, Watanabe $\mathrm{D}$, et al. Serum soluble (pro)renin receptor levels in patients with essential hypertension. Hypertens Res. 2014;37(7):642-8. https:// doi.org/10.1038/hr.2014.46.

85. Gatineau E, Gong MC, Yiannikouris F. Soluble prorenin receptor increases blood pressure in high fat-fed male mice. Hypertension. 2019;74(4):1014-20. https://doi.org/10.1161/hypertensionaha. 119.12906 Provides key evidence that soluble prorenin receptor induces blood pressure elevation possibly through a neurogenic mechanism in diseases associated with obesity.

86. Gatineau E, Cohn DM, Poglitsch M, Loria AS, Gong M, Yiannikouris F. Losartan prevents the elevation of blood pressure in adipose-PRR deficient female mice while elevated circulating sPRR activates the renin-angiotensin system. Am J Physiol Heart Circ Physiol. 2019;316(3):H506-h15. https://doi.org/10.1152/ ajpheart.00473.2018.

87. Gironacci MM, Cerniello FM, Longo Carbajosa NA, Goldstein J, Cerrato BD. Protective axis of the renin-angiotensin system in the brain. Clin Sci (London). 2014;127(5):295-306. https://doi.org/ 10.1042/cs20130450.

88. Santos RA, Simoes e Silva AC, Maric C, Silva DM, Machado RP, de Buhr I, et al. Angiotensin-(1-7) is an endogenous ligand for the $\mathrm{G}$ protein-coupled receptor mas. Proc Natl Acad Sci U S A. 2003;100(14):8258-63. https://doi.org/10.1073/pnas. 1432869100 .

89. Leonhardt J, Villela DC, Teichmann A, Munter LM, Mayer MC, Mardahl M, et al. Evidence for heterodimerization and functional interaction of the angiotensin type 2 receptor and the receptor MAS. Hypertension. 2017;69(6):1128-35. https://doi.org/10. 1161/hypertensionaha.116.08814.

90. Teixeira LB, Parreiras ESLT, Bruder-Nascimento T, Duarte DA, Simoes SC, Costa RM, et al. Ang-(1-7) is an endogenous betaarrestin-biased agonist of the AT1 receptor with protective action in cardiac hypertrophy. Sci Rep. 2017;7(1):11903. https://doi.org/ 10.1038/s41598-017-12074-3.

91. Santos RA, Ferreira AJ, Verano-Braga T, Bader M. Angiotensinconverting enzyme 2, angiotensin-(1-7) and mas: new players of the renin-angiotensin system. J Endocrinol. 2013;216(2):R1-r17. https://doi.org/10.1530/joe-12-0341.

92. Xia H, Feng Y, Obr TD, Hickman PJ, Lazartigues E. Angiotensin II type 1 receptor-mediated reduction of angiotensin-converting enzyme 2 activity in the brain impairs baroreflex function in hypertensive mice. Hypertension. 2009;53(2):210-6. https://doi.org/ 10.1161/hypertensionaha.108.123844.

93. Lambert DW, Yarski M, Warner FJ, Thornhill P, Parkin ET, Smith AI, et al. Tumor necrosis factor-alpha convertase (ADAM17) mediates regulated ectodomain shedding of the severe-acute respiratory syndrome-coronavirus (SARS-CoV) receptor, angiotensinconverting enzyme-2 (ACE2). J Biol Chem. 2005;280(34): 30113-9. https://doi.org/10.1074/jbc.M505111200.

94. Xia H, Sriramula S, Chhabra KH, Lazartigues E. Brain angiotensin-converting enzyme type 2 shedding contributes to the development of neurogenic hypertension. Circ Res. 2013;113(9):1087-96. https://doi.org/10.1161/circresaha.113. 301811.

95. Yamazato M, Yamazato Y, Sun C, Diez-Freire C, Raizada MK. Overexpression of angiotensin-converting enzyme 2 in the rostral ventrolateral medulla causes long-term decrease in blood pressure in the spontaneously hypertensive rats. Hypertension. 2007;49(4): 926-31. https://doi.org/10.1161/01.Hyp.0000259942.38108.20.

96. Mukerjee S, Gao H, Xu J, Sato R, Zsombok A, Lazartigues E. ACE2 and ADAM17 interaction regulates the activity of presympathetic neurons. Hypertension. 2019;74(5):1181-91. https://doi.org/10.1161/hypertensionaha.119.13133 Utilizing 
novel molecular tools the author provide new insights of how the protective arm of the brain RAS is regulated. This new article demonstrates the opposing contributions of ACE2 and ADAM17 in hypothalamic pre-sympathetic neurons for the development of hypertension.

97. Xue B, Yu Y, Wei SG, Beltz TG, Guo F, Felder RB, et al. Stressinduced sensitization of angiotensin II hypertension is reversed by blockade of angiotensin-converting enzyme or tumor necrosis factor-alpha. Am J Hypertens. 2019;32(9):909-17. https://doi.org/10. 1093/ajh/hpz075.

98. Carvalho-Galvao A, Guimaraes DD, De Brito Alves JL, Braga VA. Central inhibition of tumor necrosis factor alpha reduces hypertension by attenuating oxidative stress in the rostral ventrolateral medulla in renovascular hypertensive rats. Front Physiol. 2019;10:491. https://doi.org/10.3389/fphys.2019.00491.

99. Han C, Wu W, Ale A, Kim MS, Cai D. Central leptin and tumor necrosis factor-alpha (TNFalpha) in diurnal control of blood pressure and hypertension. J Biol Chem. 2016;291(29):15131-42. https://doi.org/10.1074/jbc.M116.730408.

100. Mulatero P, Verhovez A, Morello F, Veglio F. Diagnosis and treatment of low-renin hypertension. Clin Endocrinol. 2007;67(3): 324-34. https://doi.org/10.1111/j.1365-2265.2007.02898.x.

101. Grobe JL, Buehrer BA, Hilzendeger AM, Liu X, Davis DR, Xu D, et al. Angiotensinergic signaling in the brain mediates metabolic effects of deoxycorticosterone (DOCA)-salt in C57 mice. Hypertension. 2011;57(3):600-7. https://doi.org/10.1161/ hypertensionaha.110.165829.

102. Reaux A, Fournie-Zaluski MC, David C, Zini S, Roques BP, Corvol P, et al. Aminopeptidase a inhibitors as potential central antihypertensive agents. Proc Natl Acad Sci U S A. 1999;96(23): 13415-20. https://doi.org/10.1073/pnas.96.23.13415.

103. Fournie-Zaluski MC, Fassot C, Valentin B, Djordjijevic D, ReauxLe Goazigo A, Corvol P, et al. Brain renin-angiotensin system blockade by systemically active aminopeptidase a inhibitors: a potential treatment of salt-dependent hypertension. Proc Natl Acad Sci U S A. 2004;101(20):7775-80. https://doi.org/10.1073/ pnas.0402312101.

104. Ferdinand KC, Balavoine F, Besse B, Black HR, Desbrandes S, Dittrich HC, et al. Efficacy and safety of firibastat, a first-in-class brain aminopeptidase A inhibitor, in hypertensive overweight patients of multiple ethnic origins. Circulation. 2019;140(2):138-46. https://doi.org/10.1161/circulationaha.119.040070 First clinical trial demonstrating the efficacy and safety of aminopeptidase A inhibitors in hypertension associated with obesity.

105. Azizi M, Courand PY, Denolle T, Delsart P, Zhygalina V, Amar L, et al. A pilot double-blind randomized placebo-controlled crossover pharmacodynamic study of the centrally active aminopeptidase A inhibitor, firibastat, in hypertension. J Hypertens. $2019 ; 37(8): 1722-8$. https://doi.org/10.1097/hjh. 0000000000002092 .

106. Keck M, De Almeida H, Compere D, Inguimbert N, Flahault A, Balavoine F, et al. NI956/QGC006, a potent orally active, brainpenetrating aminopeptidase a inhibitor for treating hypertension. Hypertension. 2019;73(6):1300-7. https://doi.org/10.1161/ hypertensionaha.118.12499.

107. Shan BS, Mogi M, Iwanami J, Bai HY, Kan-No H, Higaki A, et al. Attenuation of stroke damage by angiotensin II type 2 receptor stimulation via peroxisome proliferator-activated receptor-gamma activation. Hypertens Res. 2018;41(10):839-48. https://doi.org/ 10.1038/s41440-018-0082-9.

108. Bennion DM, Jones CH, Dang AN, Isenberg J, Graham JT, Lindblad L, et al. Protective effects of the angiotensin II AT2 receptor agonist compound 21 in ischemic stroke: a nose-tobrain delivery approach. Clin Sci (Lond). 2018;132(5):581-93. https://doi.org/10.1042/cs20180100.
109. Panahpour H, Terpolilli NA, Schaffert D, Culmsee C, Plesnila N. Central application of Aliskiren, a renin inhibitor, improves outcome after experimental stroke independent of its blood pressure lowering effect. Front Neurol. 2019;10:942. https://doi.org/10. 3389/fneur.2019.00942.

110. Kehoe PG, Hibbs E, Palmer LE, Miners JS. Angiotensin-III is increased in Alzheimer's disease in association with amyloidbeta and tau pathology. J Alzheimers Dis. 2017;58(1):203-14. https://doi.org/10.3233/jad-161265.

111. Trigiani LJ, Royea J, Lacalle-Aurioles M, Tong XK, Hamel E. Pleiotropic benefits of the angiotensin receptor blocker candesartan in a mouse model of Alzheimer disease. Hypertension. 2018;72(5):1217-26. https://doi.org/10.1161/ hypertensionaha.118.11775.

112. Elkahloun AG, Hafko R, Saavedra JM. An integrative genomewide transcriptome reveals that candesartan is neuroprotective and a candidate therapeutic for Alzheimer's disease. Alzheimers Res Ther. 2016;8:5. https://doi.org/10.1186/s13195-015-0167-5.

113. Ho JK, Nation DA. Memory is preserved in older adults taking AT1 receptor blockers. Alzheimers Res Ther. 2017;9(1):33. https://doi.org/10.1186/s13195-017-0255-9.

114. Ho JK, Nation DA. Cognitive benefits of angiotensin IV and angiotensin-(1-7): a systematic review of experimental studies. Neurosci Biobehav Rev. 2018;92:209-25. https://doi.org/10. 1016/j.neubiorev.2018.05.005.

115. Cooper HA, Scalia R, Rizzo V, Eguchi S. Angiotensin II- and Alzheimer-type cardiovascular aging. Circ Res. 2018;123(6): 651-3. https://doi.org/10.1161/circresaha.118.313477.

116. Carvalho-Galvao A, Ogunlade B, Xu J, Silva-Alves CRA, Mendes-Junior LG, Guimaraes DD, et al. Central administration of TRV027 improves baroreflex sensitivity and vascular reactivity in spontaneously hypertensive rats. Clin Sci (Lond). 2018;132(14):1513-27. https://doi.org/10.1042/cs20180222.

117. Torika N, Asraf K, Cohen H, Fleisher-Berkovich S. Intranasal telmisartan ameliorates brain pathology in five familial Alzheimer's disease mice. Brain Behav Immun. 2017;64:80-90. https://doi.org/10.1016/j.bbi.2017.04.001.

118. Gonzalez AD, Wang G, Waters EM, Gonzales KL, Speth RC, Van Kempen TA, et al. Distribution of angiotensin type 1a receptorcontaining cells in the brains of bacterial artificial chromosome transgenic mice. Neuroscience. 2012;226:489-509. https://doi. org/10.1016/j.neuroscience.2012.08.039.

119. Sequeira Lopez ML, Pentz ES, Nomasa T, Smithies O, Gomez RA. Renin cells are precursors for multiple cell types that switch to the renin phenotype when homeostasis is threatened. Dev Cell. 2004;6(5):719-28. https://doi.org/10.1016/s1534-5807(04) 00134-0.

120. Nation HL, Nicoleau M, Kinsman BJ, Browning KN, Stocker SD. DREADD-induced activation of subfornical organ neurons stimulates thirst and salt appetite. J Neurophysiol. 2016;115(6):31239. https://doi.org/10.1152/jn.00149.2016 Demonstrated that DREADD-mediated stimulation of neurons within the subfornical organ leads to prominent dipsogenic responses and salt appetite.

121. Sapouckey SA, Deng G, Sigmund CD, Grobe JL. Potential mechanisms of hypothalamic renin-angiotensin system activation by leptin and DOCA-salt for the control of resting metabolism. Physiol Genomics. 2017;49(12):722-32. https://doi.org/10.1152/ physiolgenomics.00087.2017 In silico re-analysis of hypothalamic single-cell RNA sequencing datasets reveals that $A_{1} R$ is expressed in a specific subcluster of neurons expressing both Agouti-related peptide (AgRP) and leptin receptors.

Publisher's Note Springer Nature remains neutral with regard to jurisdictional claims in published maps and institutional affiliations. 